\title{
The Next Step: Silk Road as Metaphor, Seattle, the Silk Road, and the Pacific Rim
} Been Shaped by Several Forces

First, geography and ecology: the vast steppes and deserts, the sky-piercing mountains with pastures and forests, the long narrow riverine oases, the enormous wealth of wild plants and-formerly — wild game and fish, the savage climate. The eastern approaches are strictly summer-rainfall lands, under the monsoon; the western, from the Pamirs and western Altai, have more winter rain. Cool periods force the rainstorms south, which hurts the east-rain is held back in north China-but helps the west, because the Atlantic storm tracks are forced south from northern Europe and Russia to the Mediterranean and Central Asia. Seasonal availability of pasture led to annual movements of nomads that could cover hundreds of miles. Knowledge of resources and routes was thus critical, and necessarily encyclopedic, as anyone knows who has spent time with Central Asian herder. A veteran herder knows when each important forage or veterinary plant is available over an area that can reach thousands of square miles.

Second, the prehistory of settlement: hunter-gatherers, evidently at very low density, rapidly filled in the environment, but population was tiny until agriculture and stockraising expanded after 7000 BCE. It reached all parts of the region in the 2 nd millennium $\mathrm{BCE}$. At about that same time, toward the start of the Bronze Age, full-scale nomadism with mixed stock and portable housing emerged, spreading over the region and making much better use of vast tracts of desert and steppe. Nomad or semi-nomad hordes increasingly spread south, invading the Indian subcontinent and settling western China. Genetics influenced foodways as lactose tolerance genes spread from west to east, allowing free use of raw milk in the west. Eastward, milk was so generally soured to preserve it that there was little selection for the gene.

Third, history: conquest came from the settled, heavily populated lands, especially from Iran in the southwest and China to the southeast. Russia, especially after 1500 , contributed some important influences. The rise and fall of empires led to expanding or contracting control over Central Asia. Each expansion left a wave of cultural influences. Each contraction left the civilized 
cores open to small or massive invasions by steppe people, climaxing in the Mongol takeover of Eurasia and the later Mughal conquest of India. Thus elements of Iranic and Chinese civilization traveled far, but elements of steppe and oasis culture-often transformed from earlier Iranic and Chinese models-became important in the cores. Chinese culture was especially heavily influenced by Central Asian cultures, a story still far from fully told.

With all these came the influence of religion, which powerfully shaped the foodways of Central Asia. The first obvious shaping was the rise of vegetarianism under Buddhist influence, which — since the Buddhists were not vegansgave a powerful impetus to dairy foods. The second was the spread of Islam, which banned not only pork and (theoretically) alcohol but a whole range of other items, from blood to lizards. Other religions brought their own less obvious influences; Manichaeans favored cucumbers and melons, Christians popularized grape wine, Jews - extremely important and influential in Bukhara-taught new ways with stews.

Institutions of ownership and governance had their effect. The region lived under qans (or more accurately qanlar), leaders of lineage or clan groups who had king-like status and power but were usually under considerable control by nobles and elders. Management of resources in the oases was as fixed private property, usually owned by the lineages or other descent groups or by private families, but management of resources in the open lands-almost $99 \%$ of Central Asia - was by the great descent groups. Land was held in various forms of common hold. Access could be limited to the descent group or open to many, usually with permission. Raiding and fighting over pasture, valley, and stock was a major way of life. War was expected, and welcomed by young men as a source of honor and power. All this shaped foodways, most importantly by forcing leaders to be generous; a leader who did not feast his clients and friends found himself abandoned, in a world where lack of backers meant almost instant destruction.

Above all, the high mobility of the region guaranteed that foodways would spread. From the Xiongnu crossing Eurasia to become the Huns down to modern Koreans settling in Kazakhstan, people have not stood still. Under the circumstances, it is slightly surprising that Chinese food has not traveled farther, but here we circle back to the beginning: geography and ecology forbid the cultivation of many Chinese crops, and the high mobility of most of the population made difficult the enormous processing and fermentation technology necessary to Chinese and Korean food. Iranian food, better adapted to the camp and the open fire, triumphed in most of the region. 
Thus the lay of the land gives basic but broad constraints; history, religion, and culture fine-tune the foodways, creating a rich, diverse texture with many determinants.

Sea traffic was an important part of the international exchange system implicit in the Silk Road from the beginning. ${ }^{1}$ At first voyages were short and little more than coasting, and highly dangerous. Later voyages were attempted across the open sea, when the monsoons were discovered in the Indian Ocean and sailing became easier for long and short range, and as ships got bigger and stronger. By then a system of enterpots, set harbors at strategic locations where goods could be exchanged and transshipped had developed. Still later direct voyages began, from far away China in larger and larger ships, across the Indian Ocean to Iran where the voyages connected to land routes, one leading to Shiraz and from Shiraz to Trebizond. ${ }^{2}$ From there the Europeans, particularly the Genoese, took the shipments.

After the fall of the Mongol state in the Near East, direct contracts from China were interrupted. Yuan soon fell too, removing the Mongol-era incentives for much long-distance trade. The great Ming voyages, on a hitherto unparalled scale, briefly renewed and even expanded the tradition of grand Indian Ocean sailing from China. Unfortunately, Ming was unable to sustain them. A real maritime age had to wait for the Portuguese. After 1498, they tied the Indian Ocean directly to Europe and beyond the Indian Ocean to China and Japan. It remained for the Spanish to initiate the direct sailings across the Pacific in their Manila Galleon (after 1565), which when hooked into Atlantic traffic began a true global age-one not just confined to the Old World.

Since 1565 many new ports and urban centers with long-distance ocean contacts have arisen, including many in the New World — great ports such as New York, Seattle, San Francisco and Acapulco, termiunal of the Manila Galleon. The world is interconnected in ways unimagined before 1565 , and this interconnection is growing. Today a new land-based Silk Road runs across Xinjiang, with a planned rail line uniting Kazakhstan and China as major trading partners. Air traffic too has attained unparalled levels. The hubs are often places once connected by traditional land and water routes. The old routes are revived; connections are enhanced.

1 Cunliffe, By Steppe, Desert, and Ocean.

2 Ciocilltan, The Mongols and the Black Sea Trade in the Thirteenth and Fourteenth Centuries. 
Among the new cities of the post-Manila Galleon era is modern Seattle. Although a recent establishment, about 1851 , it is now a gigantic presence on the Pacific Rim. As a city, it is in many ways an extension of Asia, not just full of Asian settlers and visitors, but in every respects an international community and culture. Seattle not only has trading connections with Japan, Korea, China and beyond. In every respect it has substantial demographic connections with Asia. In 2010, with an official urban area population of 608,660 , it was reported that $13.8 \%$ of the population was Asian or Asian-American, and the percentage in some suburbs may well be higher still. The Chinese have been there from the beginning, as have the Japanese, although the Japanese received a setback due to discrimination in WWII. More recently, as a result of the Southeast Asian wars, Seattle has taken in large numbers of Vietnamese and Cambodians, and now many other Asian groups, even individuals from such small minorities as the Yu-Mien (Seattle even has a large Tibetan community and a few Mongols).

Its Asian presence creates not only a demographic effect. There are major cultural impacts as well, including food. Seattle has several large Asian supermarkets with an amazing range of foods for sale and varieties of foods that accord with the interests of the Asian populations. Restaurant fish tanks imply instant death for large numbers of fish to achieve freshness. There is always an impressive variety of vegetables - more than one finds in most cities. Ordinary and specialty teas are available in profusion; hundreds of varieties are sold in the Asian supermarkets and specialty stores. Seattle's Asian restaurant culture rivals many an East Asian city. People of all origins and backgrounds now shop in those markets and eat at those restaurants; it is common to see people with backgrounds from four different continents happily mixing at the same table at a Chinese watering hole. And the food is mixed too, not just by nationality but including purely traditional Asian foods along side those with connections to the Eurasian heartland, from Baozi to Mandu and beyond. Korean restaurants abound, and a northwest Chinese restaurant serving thoroughly Central Asian-style food had a long career near the University of Washington.

Because of its demographics and the cultural presence of Asians, and its trade orientation and links to a larger trading zone, Seattle resembles in many ways the old Silk Road communities and the associated maritime world. It is in fact a Silk Road city in every way, a Silk Road city as metaphor. In fact, the entire world has now become part of a global silk road and all of its interactions and exchanges that came together so long ago but persists in new forms today.

Thus Seattle is a good place to stop. It is a New World city but also one that has in many ways developed, like much of China, from deep Eurasian links affecting everything from crops to herbs and spices and foods. It is all here, just moved across the pacific with a little help from the Manila Galleon, and the 
Asian goods and people that first came with it, and now arrive by air or on great cargo vessels.

\section{$3 \quad$ A Final Word}

The story of the food of Central Asia is a story of travels, meetings, interactions, borrowings, and trade. Since long before modern humans arose, the region was one in which different human groups could meet, mix, and create new worlds. Being about equally far from China, India, the Mediterranean, and Europe, on good trade routes, it could take advantage of a wide range of goods and ideas.

Much of the interaction was violent; the region has always been warlike. Much was trade between strangers. Most was less dramatic: ordinary contacts between people, in nomad camps, in villages, in cities, in mountain pastures. Through these contacts, foods from the known world were transmitted throughout the Eurasian continent. The slow spread of wheat and barley in Neolithic times led to the faster spread of new crops in the middle ages, and New World foods still later.

The rise of the Silk Road (or roads) led to a golden age. Not only did trade flourish, but Central Asia was briefly the world center of nutritional science. The great medical writers Al-Birūni and Ibn Sīnā (Avicenna) were only the most conspicuous of many brilliant writers who could take advantage of available science from Europe to India. Medical and nutritional knowledge spread to China and elsewhere. This was part of a vast Eurasia-wide exchange of religions, philosophies, art styles, sciences, and all else that makes life interesting.

The rise of the Mongol and Turkic warlords impacted but did not stop science and trade, but the Little Ice Age and the rapid expansion of sea trade on the "Maritime Silk Roads" ended the importance of the Central Asian routes. Central Asia declined. It is now rising again, through a combination of mineral and agricultural wealth, revived land trade (and air trade), and local dynamism.

Throughout the region, we see the importance of the basic framework of Near Eastern Neolithic staples: wheat, barley, chickpeas, sheep, goats, cattle, onions and garlic. Grapes came from the Caucasus region. Central Asia contributed the horse and the apple tree, domesticated in what is now Kazakhstan. Apricots and Persian walnuts are native to Central Asian mountains. Tea from China, mung beans from India, carrots from the Mediterranean, and other crops came in the medieval period. Chiles, tomatoes, green beans, squash, potatoes, and maize came from the New World after 16oo. Central Asian food today is an eclectic mix of ingredients from all corners of the world, 
but remains rather conservative in recipes. Bread remains the staple. Roasts, stews, dumplings, noodles, and soups are the usual culinary forms. Recipes spread widely, food being identifiably similar from Kazakhstan to Xinjiang. Islam has influenced foodways strongly by eliminating pigs, horses, and-less universally — wine from the diet in Islamic lands.

The lessons of Central Asia include a whole curriculum on the advantages of learning from your neighbors. Part of that curriculum involves respect, a very important teaching in Central Asian cultures. Today, as people try to balance globalization and local independence, we can find instruction by considering the experiences of Central Asians over time. Some of the examples are negative ones, such as the horrible meltdowns under warlords like Tamerlane (Timur-i Lenk), the decline due partly to climate in the Little Ice Age, the brutal excesses of invasive colonialism in the 19th and 2oth centuries, and the mismanagement that dried the Aral Sea and is impacting many other areas. Other examples are more inspiring: openness to trade over most of history, the artloving and science-conscious society of the 11 th and 12 th centuries, the modern efforts in at least some nations to establish democracy.

Today, with a Uighur restaurant in Sydney, a Mongolian one in San Francisco, and an Uzbek one in Los Angeles, the Silk Road is the world. Central Asian food has thereby become part of a wider story of human enterprise, change, adaptation, and conflict. Food is a major part of a wider story of migration, war, trade, learning, art, politics, and of sheer human toughness and flexibility in a difficult and demanding environment. 